\section{Production of High- quality Composts for Horticultural Purposes: A Mini-review}

\author{
Michael Raviv
}

AdDITIONAL INDEX wORDs. container medium, organic farming, physical characteristics, soil organic matter, suppressiveness

SuMMARY. Compost is organic matter that has undergone partial thermophilic, aerobic decomposition. This environmentally safe process is called composting. The combination of raw materials and the chosen composting method yields a wide range of characteristics, such as organic matter (OM) content, nutrient content, potential for disease suppressiveness and other physical, chemical, and biological properties. The objectives of this review are describing the horticultural outlets for composts, defining compost characteristics important for the above uses, and describing composting procedures and raw materials leading to these characteristics. The two main horticultural uses of composts are as soil amendment and as an ingredient in container media. Soilapplied composts improve soil fertility mainly by increasing soil organic matter (SOM) that activates soil biota. Compost's nutrient content, and especially that of nitrogen $(\mathrm{N})$, should be high (>1.8\%). Composts having these characteristics are produced of raw materials rich in both $O M$ and $\mathrm{N}$, while minimizing their loss during composting. Typical raw materials for this purpose include animal manures, offal, abattoir residues, sewage sludge, and grass clippings. Various composting methods can yield the required results, including turned windrows, aerated static piles, and in-vessel composting. Composts are also used for substrates as low-cost peat substitute, potentially suppressive against various soilborne diseases. These composts must be stable and non-phytotoxic. Physical properties of compost used as substrate are important. Hydraulic conductivity, air porosity, and available water should be high. Reconciling the physical and

Agricultural Research Organization, Newe Ya'ar Research Center, P.O.B. 1021 Ramat Yishay 30095, Israel. E-mail: mraviv@volcani.agri.gov.il biological demands may be difficult. Materials such as softwood bark, wood shavings, various types of shells or hulls, and coconut coir are characterized by good physical properties after composting. However, being relatively resistant to decomposition, these materials should be subjected to long and well-controlled composting, which may be shortened using $\mathrm{N}$ and $\mathrm{N}$-rich organic matter such as animal manures. High temperatures $\left[>65^{\circ} \mathrm{C}\left(149.0^{\circ} \mathrm{F}\right)\right]$ may cause ashing, which leads to reduced porosity. In addition to ligneous materials, composts serving as growing media may be produced from numerous organic wastes, such as manures, food industry wastes, etc. These materials are better composted in aerated static piles, which tend to minimize physical breakdown. Animal excreta are of special value for co-composting as they contain large, diverse populations of microorganisms, which accelerate the process.

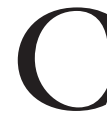
ompost is a general term, describing all organic matter that has undergone a long, thermophilic, aerobic stabilization process (i.e., composting). Composts may vary with raw material(s) used, and duration and nature of the composting process. The combination of these factors results in a wide range of characteristics and qualities of the end-product. Affected characteristics include physical, chemical, and biological properties of the end-products, such as biological oxygen demand (BOD), OM content, nutrient content, and the degree of disease suppressiveness.

The various resulting compost types can find adequate outlets, according to the intended use. It is intuitively clear that highly intensive uses such as container media demand composts of high quality, while lowvalue outlets such as mine reclamation are less demanding.

The absence of direct communication between compost producers and consumers is, perhaps, the highest obstacle for a more widespread use of composts. On the one hand, compost producers are not well aware of the agronomic and horticultural uses of composts and, hence, do not make efforts to control their production methods so as to meet the consumers' demands and to ensure stable and reproducible quality of the product. On the other hand, growers are not well educated as to the effect of compost quality on the horticultural performance of their growing systems. As a result, they look for cheap products and tend to ignore the unavoidable connection between quality and cost. An interesting example for a different situation can be found in Israeli kibbutzim that practice organic farming. There, the animal manure and other organic wastes are composted and later on applied onto the fields and orchards of the same kibbutz. In this case, the daily dialogue among the producers and consumers leads to near-optimal results.

The popularity of treating organic wastes by means of composting has been steadily growing in the last three decades. Unlike other treatment methods for organic waste, such as land-filling or incineration, which may cause severe pollution due to leachates reaching groundwater or air pollution, composting is considered as a much safer process (Dalemo, 1999; Harrison and Hester, 2002). It is a method that turns waste into resource and enables restoring depleted soil organic matter. Once produced properly, compost turns into a beneficial product for agriculture.

On the consumption side, the use of composts for various application types is steadily growing over the years, as well. Growers realized that compost can serve as an economical source of nutrients, that it improves soil physical properties, and that it can be used as a low-cost ingredient in soilless media. In this application type, it may also reduce the need for media disinfestation or for fungicide drenches, due to suppressive effects found on many occasions, on a number of root pathogens (Hoitink and Kuter, 1986). Repeated land application of compost can render soils suppressive to soilborne diseases (Lumsden et al., 1986).

The objectives of this review are to describe the main horticultural outlets for composts and their requirements; define specific characteristics of composts important for the above horticultural uses; and describe composting procedures and raw materials that lead to the required characteristics.

\section{Horticultural usages of composts}

The two main horticultural uses of composts are as soil amendment for vegetable and fruit crops, and as an ingredient in container media. 
COMPOST FOR SOIL APPLICATION. Compost intended to serve as soil amendment is applied in order to improve soil fertility. In many cases prolonged intensive agronomical or horticultural cultivation causes gradual depletion of SOM (Acosta-Martinez et al., 2003; Romkens et al., 1999). Reduced SOM is frequently associated with lower soil biological activity (Garcia and Hernandez, 1997) and with deteriorating soil's physical properties (Jordahl and Karlen, 1993). The result is an overall reduced soil fertility (Bauer and Black, 1994). Repeated application of various types of organic matter, and especially of compost can reverse this negative process (Grandy et al., 2002; Jordahl and Karlen, 1993). Quantitative parameters that are affected by organic amendments include soil biomass (Lee et al., 2004), soil respiration (Sikora and Rawls, 2000), various enzymatic activities (Antonious, 2003), nitrification rate (Bernal et al., 1998), large aggregate stability (Grandy et al., 2002), water infiltration rate and hydraulic conductivity (Zeytin and Baran, 2003), and water holding capacity (Punshon et al., 2002). If done properly and for relatively long period (5-10 years, depending upon climatic conditions, soil management and soil type), original soil fertility can be restored.

REQUIRED COMPOST CHARACTERISTICS. The main effects of soil-applied composts are on soil biology, plant nutrition (either directly and/or through its effect on nutrient cycling), and on soil physical characteristics. Composts having high OM (typically $>40 \%$ ) positively affect soil fertility, due both to its effect on soil biota and on soil physical characteristics. Composts can also be applied as a direct source of nutrients. This situation is typical of organic farming systems, where composts serve as the sole or one of the main sources of plant nutrition because application of synthetic fertilizers is not allowed while organic fertilizers are usually expensive. To satisfy nutritional requirements of many crops, typically high $(>1.8 \%) \mathrm{N}$ content is required as a plant nutrient. An example for such stable and nutritious compost is shown in Table 1 ( $M$. Raviv, unpublished). Typical nutritional contents of composts, adequate for using in different soils, can be found in Wolf and Snyder (2003).

Young composts are usually rich in polysaccharide content (Sela et al.,

Table 1. Characteristics of raw mixture ( $0 \mathrm{~d})$, young $(74 \mathrm{~d})$, and stable (111 d) compost, made of the coarse fraction of 2 cattle manure: 1 wheat straw (by volume $)^{\mathrm{z}}$ (M. Raviv, unpublished).

\begin{tabular}{lccc}
\hline & \multicolumn{3}{c}{ Compost type } \\
\cline { 2 - 4 } Characteristic & Raw & Young & Stable \\
\hline Compost age $(\mathrm{d})$ & 0 & 74 & 111 \\
Organic matter $(\%)$ & 74.8 & 55.7 & 53.3 \\
Nitrogen $(\%)$ & 1.67 & 2.17 & 2.39 \\
Phosphorous (\%) & 0.52 & 0.79 & 0.74 \\
Potassium $(\%)$ & 1.31 & 1.79 & 2.11 \\
pHy & 7.6 & 7.5 & 6.8 \\
Electrical conductivity $\left(\mathrm{dS} \cdot \mathrm{m}^{-1}\right)^{\mathrm{y}}$ & 4.02 & 5.76 & 7.74 \\
Nitrate nitrogen $\left(\mathrm{mmol} \cdot \mathrm{L}^{-1}\right)^{\mathrm{y}}$ & 0.01 & 0.3 & 164.4 \\
Ammonium nitrogen $\left(\mathrm{mmol} \cdot \mathrm{L}^{-1}\right)^{\mathrm{y}}$ & 0.9 & 14.9 & 19.5 \\
Soluble organic nitrogen $\left[\mathrm{mg} \cdot \mathrm{L}^{-1}(\mathrm{ppm})\right]^{\mathrm{y}}$ & 142.9 & 98.7 & 81.5 \\
Carbon : nitrogen ratio & 26 & 15.1 & 13.1 \\
Biological oxygen demand $\left(\mathrm{g} \cdot \mathrm{kg}^{-1} \cdot \mathrm{d}^{-1}\right)$ & 16.1 & 9.3 & 4.7 \\
\hline
\end{tabular}

${ }^{2}$ Composting was done in an aerated static pile, turned at days 28 and 78 .

yn a 10:1 aqueous extract; $1 \mathrm{mmol} \cdot \mathrm{L}^{-1}=1 \mathrm{meq} \cdot \mathrm{L}^{-1}$.

1998). Polysaccharides enhance flocculation of partly dispersed soil and increase its large aggregate stability, thus restoring its original physical properties. Applying young compost, however, dictates a long stabilization period before planting. An example for the characteristics of young composts is shown in Table 1.

The required characteristics of stable and young composts are substantially different (Table 1). Differing parameters are, for example, BOD and nitrate content. The first one reflects the continued decomposition of biodegradable compounds with composting time, such as hemicellulose (Raviv et al., 1987). The second parameter results from enhanced activity of nitrifying bacteria when the compost temperature drops below $\sim 40{ }^{\circ} \mathrm{C}\left(104.0^{\circ} \mathrm{F}\right)$.

CoMposting FOR HIGH-QUALITY COMPOSTS. In order to produce composts having the above-mentioned characteristics, raw material rich in both $\mathrm{OM}$ and $\mathrm{N}$ should be used, and the composting procedure should minimize OM and $\mathrm{N}$ loss. Typical raw materials adequate for this purpose include animal manures, animal offal and abattoir residues, sewage sludge, and grass clippings. The subject of $\mathrm{N}$ loss during composting and ways to minimize its rate are discussed by Raviv et al. (2004). N loss during composting is usually quite high, and typical values are around 50\% (Eghball et al., 1997; Martins and Dewes, 1992; Vuorinen and Saharinen, 1998). Most $\mathrm{N}$ is lost to the atmosphere as ammonia (Eghball et al., 1997; Tiquia and Tam, 2000). Three main factors contribute to ammonia volatilization during composting of organic wastes: initial low carbon : nitrogen $(\mathrm{C}: \mathrm{N})$ ratio (Larsen and McCartney, 2000), high pH (Korner and Stegmann, 1998), and high oxygenation rate (Michel and Reddy, 1998). Nitrogen loss during composting may be reduced by using high $\mathrm{C}: \mathrm{N}$ mixtures that enhance $\mathrm{N}$ immobilization, or by lowering the $\mathrm{pH}$ of the compost solution, which shifts the balance between ammonium ions and dissolved ammonia toward the former, thus reducing ammonia volatilization during the thermophilic stage of composting (Ekinci et al., 2000). Moderating the airflow rate through the compost pile is another way of lowering ammonium volatilization (Vuorinen and Saharinen, 1998). High temperatures $\left[>70{ }^{\circ} \mathrm{C}(158.0\right.$ $\left.{ }^{\circ} \mathrm{F}\right)$ ] during the thermophilic stage of composting lead to rapid loss of organic matter, resulting in a significant loss of N (Sanchez-Monedero et al., 1996). Hence, maintaining moderate temperatures $\left(<65{ }^{\circ} \mathrm{C}\right)$ is another means of lowering N loss (Raviv et al., 1999). After decomposition of nitrogenous compounds, ammonium ions can be removed from the compost solution and adsorbed onto surfaces of materials having high cation exchange capacity (CEC), such as zeolite. Adding such materials $(25 \%$, by weight $)$ can reduce ammonia volatilization (Witter and Kirchmann, 1989).

Various composting procedures can yield the required results, including turned windrows, aerated static piles, and in-vessel composting. Normally, the economics of turned windrows is 
more favorable, while the other two methods provide better control.

\section{Compost as an ingredient in container media}

In addition to the age-old use of compost as soil amendment, the importance of its use as a constituent in container media is steadily growing. There are three main reasons for this trend: 1) In many cases, nonedible crops, such as ornamentals, forest and garden trees and shrubs, etc., can serve as a safe outlet for composts that may be considered as nondesirable for food crop production. 2) Various composts act as well as peat moss does in container media, while their cost is considerably lower. 3 ) Mature composts may suppress many soilborne diseases. Reviews describing the production and use of composts as growing media were written by Miller and Metting (1992), Inbar et al. (1993), Epstein (1997), Raviv (1998a), and Raviv et al. (2002). The use of bark and wood composts as growing media was reviewed by Gartner and Williams (1978), Worrall (1978), Pokorny (1979), Aaron (1982), Riviere and Milhau (1984), Pudelski (1985), Bunt (1988), Miller and Jones (1995), and Benoit and Ceustermans (1995).

Peat moss is widely used as a stand-alone medium or as an ingredient in growing media. It attained this important position due to its excellent physical properties. The main relevant properties are its high air-filled porosity (AFP) and easily available water (EAW) under conditions of container capacity, i.e., after the end of free drainage (Bunt, 1988). Simultaneously, peat's hydraulic conductivity under these conditions is high (da Silva et al., 1993; Heiskanen, 1995, 1999). Another positive characteristic of peat is its high oxygen diffusion rate (ODR) (Bunt, 1991). Yet growers and researchers throughout the world have been looking for peat substitutes for almost three decades now. The initial drive for replacing peat in growing media was its high cost. In addition, researchers found that peat is a conducive substrate for numerous soilborne diseases (Hoitink et al., 1977). The sterilization of peat does not alleviate the problem, as it leaves a biological vacuum that can easily be filled by pathogenic fungi. Once it was established that mature compost can counteract this phenomenon (Hoitink, 1980), its use together with or as a substitute for peat became commonplace. In addition, ecological considerations, such as the role of peat bogs in atmospheric carbon dioxide $\left(\mathrm{CO}_{2}\right)$ assimilation and their role in ensuring groundwater quality, call for peat replacement with other, renewable organic substrates.

REQUIRED COMPOST CHARACTERISTICS. The use of young composts that can be tolerated for land application is not possible when compost constitutes a major part ( $>10 \%$ by volume) of the rhizosphere, as is the case in container media. Young composts frequently contain phytotoxic organic molecules (Wu et al., 2000). As young composts still contain readily biodegradable compounds, they can undergo secondary biodegradation, leading to oxygen and $\mathrm{N}$ deficiencies in the rhizosphere. Therefore, composts used as substrates must be stable. Although compost stability is not identical to compost maturity, mature composts are necessarily stable. Therefore, compost maturity, being a prerequisite for its suppressiveness of many soilborne diseases (Nelson and Hoitink, 1983), also ensures the required stability.

The physical properties of compost used as a container medium are of major importance; hydraulic conductivity (both under saturated and unsaturated conditions) should be high, as should its AFP and EAW (Raviv and Medina, 1997). When used in soilless media, both immediate and slow-release contribution of nutrients must be taken into consideration. Otherwise, excessive vegetative growth and/or salinity effects may occur. Salinity and excessive concentrations of phytotoxic ions can be easily taken care of by leaching. The question of nutrients is more complex. Long and complicated incubation experiments may be necessary in order to predict availability of gradually released nutrients and to take that into account in the nutritional program of the crop (Hadas and Portnoy, 1994, 1997).

It must be reiterated that unless all these requirements are met simultaneously, the compost may fail to serve successfully as a container medium. This may be the reason why Cull (1981) stated "Of the nine major organic materials reviewed, not one stands out as the alternative to peat in the U.K." Since then, a wide variety of materials has been composted and served successfully as components of container media, and clear criteria of the suitability of such composts have been described (Inbar et al., 1993; Raviv et al., 1986).

Physical Characteristics. Physical characterics of composts vary greatly. At the two extremes of the scale are sewage sludge-bark compost [bulk density (BD) $0.4 \mathrm{~g} \cdot \mathrm{cm}^{-3}(0.23$ $\mathrm{Oz} /$ inch $^{3}$ ), total porosity (TP) $73 \%$, AFP 17\%, and EAW 10\% (Nappi and Barberis, 1993)] and compost made of rice hulls with $20 \%$ cow manure [BD $0.11 \mathrm{~g} \cdot \mathrm{cm}^{-3}\left(0.06 \mathrm{oz} / \mathrm{inch}^{3}\right)$, TP $94 \%$, AFP 46\%, and EAW 25\% (M. Raviv and Y. Mor, unpublished)]. Compost made of the coarse fraction of separated cattle manure is closer to the middle of the scale, with BD $0.18 \mathrm{~g} \cdot \mathrm{cm}^{-3}$ $\left(0.10 \mathrm{oz} / \mathrm{inch}^{3}\right)$, TP $92 \%$, AFP $21 \%$, and EAW 23\%, (Raviv et al., 1998b). It can be concluded that composts can be tailor-made for a wide variety of requirements related to physical properties. Many types of compost with high and low TP (e.g., most sewage sludge and MSW composts) can serve only as minor ingredients in potting mixes. Their proportion can be higher, however, when high yield or fast growth rate are less important. On the other hand, composts with high TP and AFP, such as compost made of the coarse fraction of cow manure and grape marc, can replace peat moss successfully and even serve on their own (Inbar et al., 1986; Raviv et al., $1998 b, 1998 c)$.

Chemical characteristics. A beneficial effect of including compost in a growth medium is its nutritional contribution. Nonmature compost can immobilize a significant amount of $\mathrm{N}$, but once stabilized, compost acts, to a large extent, as a slow-release fertilizer (Jespersen and Willumsen, 1993; Williams and Nelson, 1992). Most composts have $\mathrm{pH}$ values slightly above the desirable range (Nappi and Barberis, 1993). This can be corrected during plant growth by applying nitric or phosphoric acids as sources of $\mathrm{N}$ and phosphorus, respectively.

Biological CHARACTERISTICS. Many mature composts suppress a large range of phytopathogenic fungi after undergoing a curing stage (Hadar and Gorodecki, 1991; Hoitink and Kuter, 1986; Mandelbaum and Hadar, 1990). Sterilization largely inhibits this phenomenon (Mandelbaum et al., 1988; Raviv et al., 1998d; Reuveni et al., 2002), suggesting that most of it results 
from microbial activity, although some residual activity is probably related to fungistatic compounds existing in the composts (Hoitink and Fahy, 1986).

COMPOSTING FOR HIGH-QUALITY composts. The main expectations from composts used for container media are of physical (high AFP, high EAW) and of biological (low BOD, suppressiveness) natures. Reconciling these demands is not always straightforward. Materials such as softwood bark, wood shavings, rice hulls, and coconut coir are usually characterized by good physical properties after composting. However, as these materials are relatively resistant to decomposition, compost operators tend to assume that they are ready before full maturation is actually achieved. In such a case, they may undergo secondary breakdown while in the container, which may be accompanied by high $\mathrm{N}$ consumption by microorganisms. It interferes with standard, predictable plant nutrition and results with less-than-satisfactory plant performance (Handreck, 1992a, $1992 \mathrm{~b})$. It is therefore clear that these types of raw materials should be subjected to long and well-controlled composting, normally conducted in well-controlled turned windrows. The composting of these raw materials may be shortened using $\mathrm{N}$ and $\mathrm{N}$-rich organic matter such as animal manures. High temperatures may cause ashing of these materials, which lead to reduced porosity and increased bulk density. Temperatures must be controlled carefully and values above $65^{\circ} \mathrm{C}$ are not desirable.

Compost disease suppressiveness is clearly linked with the compost degree of maturity, although excessively stabilized composts tend to lose suppressiveness capacity (Hoitink and Grebus, 1997).

In addition to the more ligneous materials, composts serving as growing media may be produced from numerous organic wastes: sewage sludge, municipal solid waste, animal excreta, and wastes of food industry, such as rice hulls, corn cobs, etc. Materials having a high C:N ratio, such as yard, municipal, and agricultural trimmings, can be composted on their own or, preferably, co-composted with materials of low AFP and/or rich in N, such as sewage sludge, chicken manure, and slaughterhouse wastes. In such cases, they will serve as bulking agents and $\mathrm{N}$ traps (Genevini et al., 1997).
Animal excreta are of special value for both composting and co-composting because they contain large, diverse populations of microorganisms, which accelerate the process.

Wastes of the food and processing industry are especially convenient for composting since they are uniform, rich in organic matter, and concentrated in place. In some cases, the physical and chemical characteristics of these composts make them suitable to serve as components in container media, thus greatly increasing their economic value. A few examples for such raw materials are apple pomace (van de Kamp, 1986), sugar-cane fiber (bagasse) (Trochoulias et al., 1990), vegetable residues (Vallini et al., 1992), olive marc (Pages et al., 1985), grape marc (Inbar et al., 1986), grape stalks and corn cobs (Accati et al., 1996), fish and crab wastes (Mathur et al., 1990), and cotton gin waste (Wang, 1991). Various types of shells or hulls are particularly useful due to their inherent stability and good physical properties. Examples are rice hulls (Accati et al., 1996; Einert and Baker, 1973) and peanut hulls (Bilderback, 1982). As a general rule, both turned windrow composting and in-vessel composting tend to exert a negative effect on the physical properties of the end-products of many of these raw materials. It is therefore recommended to stabilize them using static piles that are turned only rarely, in order to ensure proper homogenization.

\section{Conclusions}

It can be concluded that the large variety of types of raw materials, composting procedures, and possible composting durations allows an almost endless flexibility in terms of the resulting compost types. In many cases the relevant know-how exists, and obtaining the required product is a matter of communication between the compost producer and consumers. Even if precise recipes do not exist, understanding the expectations of the consumer can lead to a gradual process of optimization. Open minds and open channels are the most valuable tools in the quest for ideal composts.

\section{Literature cited}

Aaron, J.R. 1982. Conifer bark: Its properties and uses. Forestry Commission, U.K. Forest Record No. 110.
Accati, E., M. Raviv, M. Devecchi, and S. Assone. 1996. Use of alternative media for bedding plant production. Agricoltura Mediterranea 126:105-112.

Acosta-Martinez, V., S. Klose, and T.M. Zobeck. 2003. Enzyme activities in semi-arid soils under conservation reserve program, native rangeland, and cropland. J. Plant Nutr. Soil Sci. 166:699-707.

Antonious, G.F. 2003. Impact of soil management and two botanical insecticides on urease and invertase activity. J. Environ. Sci. Health B. 38(4):479-88

Bauer, A. and A.L. Black. 1994. Quantification of the effect of soil organic matter content on soil productivity. Soil Sci. Soc. Amer. J. 58:185-193.

Benoit, F. and N. Ceustermans. 1995. A decade of research on ecologically sound substrates. Acta Hort. 408:17-29.

Bernal, M.P., A.F. Navarro, M.A. SanchezMonedero, A. Roig, and J. Cegarra. 1998. Influence of sewage sludge compost stability and maturity on carbon and nitrogen mineralization in soil. Soil Biol. Biochem. 30:305-313.

Bilderback, T.E. 1982. Container soils and soilless media. In: Nursery crops production manual. North Carolina State Univ., Agr. Ext. Serv., Raleigh.

Bunt, A.C. 1988. Media and mixes for container-grown plants. Unwin Hyman, London.

Bunt, A.C. 1991. The relationship of oxygen diffusion rate to the air-filled porosity of potting substrates. Acta Hort. 294:215-224.

Cull, D.C. 1981. Alternatives to peat as container media: Organic resources in the U.K. Acta Hort. 126:69-81.

Dalemo, M. 1999. Environmental systems analysis of organic waste management: The ORWARE model and the sewage plant and anaerobic digestion submodels. Acta Universitatis Agriculturae Sueciae Agraria No. 146.

da Silva, F.F., R. Wallach, and Y. Chen. 1993. Hydraulic properties of sphagnum peat moss and Tuff (scoria) and their potential effects on water availability. Plant Soil 154:119-126.

Eghball, B., J.F. Power, J.E. Gilley, and J.W. Doran. 1997. Nutrient, carbon, and mass loss during composting of beef cattle feedlot manure. J. Environ. Quality 26:189-193.

Einert, A.E. and C.E. Baker. 1973. Rice hulls as a growing medium component for cut tulips. J. Amer. Soc. Hort. Sci. 98:556-558. 
Ekinci, K., H.M. Keener, and D.L. Elwell. 2000. Composting short paper fiber with broiler litter and additives. Part I: Effects of initial $\mathrm{pH}$ and carbon/nitrogen ratio on ammonia emission. Compost Sci. Utilization 8(2):160-172.

Epstein, E. 1997. The science of composting. Technomic Publ., Lancaster, Pa.

Garcia, C. and T. Hernandez. 1997. Biological and biochemical indicators in derelict soils subject to erosion. Soil Biol. Biochem. 29:171-177.

Gartner, J.B. and D.J. Williams 1978. Horticultural uses for bark: A review of current research. Bul. Tech. Assn. Pulp Paper Ind. 61:83-86.

Genevini, P., F. Adani, and C. Villa. 1997. Rice hull degradation by co-composting with dairy cattle slurry. Soil Sci. Plant Nutr. 43:135-147.

Grandy, A.S., G.A. Porter, and M.S. Erich. 2002. Organic amendment and rotation crop effects on the recovery of soil organic matter and aggregation in potato cropping systems. Soil Sci. Soc. Amer. J. 66:1311-1319.

Hadar, Y. and B. Gorodecki. 1991. Suppression of germination of sclerotia of Sclerotium rolfsii in compost. Soil Biol. Biochem. 23:303-306.

Hadas, A. and R. Portnoy. 1994. Nitrogen and carbon mineralization rates of composted manures incubated in soil. J. Environ. Quality 23:1184-1189.

Hadas, A. and R. Portnoy. 1997. Rates of decomposition in soil and release of available nitrogen from cattle manure and municipal solid waste composts. Compost Sci. Utilization 5(3):48-54.

Handreck, K.A. 1992a. Rapid assessment of the rate of nitrogen immobilization in organic components of potting media. 1 . Method development. Commun. Soil Sci. Plant Analysis 23:201-215.

Handreck, K.A. 1992b. Rapid assessment of the rate of nitrogen immobilization in organic components of potting media. 2. Nitrogen drawdown index and plant growth. Commun. Soil Sci. Plant Analysis 23:217-230.

Harrison, R.M. and R.E. Hester. 2002. Environmental and health impact of solid waste management activities. Royal Soc. Chem., Cambridge, U.K.

Heiskanen, J. 1995. Physical properties of two-component growth media based on Sphagnum peat and their implications for plant-available water and aeration. Plant Soil 172:45-54.
Heiskanen, J. 1999. Hydrological properties of container media based on sphagnum peat and their potential implications for availability of water to seedling after outplanting. Scandinavian J. For. Res. 14:78-85.

Hoitink, H.A.J. 1980. Composted bark, a lightweight growth medium with fungicidal properties. Plant Dis. 64:142-147.

Hoitink, H.A.J. and P.C. Fahy. 1986. Basis for the control of soilborne plant pathogens with composts. Ann. Rev. Phytopathol. 24:93-114.

Hoitink, H.A.J. and M.E. Grebus. 1997. Composts and the control of plant diseases, p. 359-366. In: Hayes, M.H.B. and W.S. Wilson (eds.). Humic substances in soils, peats and waters: Health and environmental aspects. Royal Soc. Chem., Cambridge, U.K.

Hoitink, H.A.J. and G.A. Kuter. 1986. Effects of composts in growth media on soilborne pathogens, p. 289-306 In: Y. Chen and Y. Avnimelech (eds.). Organic matter in modern agriculture. Martinus Nijhof/Dr. W. Junk Publ., Dordrecht, The Netherlands.

Hoitink, H.A.J., D.M. Van Doren, Jr., and A.F. Schmitthenner. 1977. Suppression of Phytophthora cinnamomi in a composted hardwood bark potting medium. Phytopathology 67:561-565.

Inbar, Y., Y. Chen, and Y. Hadar. 1986. The use of composted separated cattle manure and grape marc as peat substitute in horticulture. Acta Hort. 178:147-154.

Inbar, Y., Y. Chen, and H.A.J. Hoitink. 1993. Properties for establishing standards for utilization of composts in container media, p. 668-694. In: H.A.J. Hoitink and H.M. Keener (eds.). Science and engineering of composting. Ohio State Univ. Press, Columbus

Jespersen, L.M. and J. Willumsen. 1993. Production of compost in a heat composting plant and test of compost mixtures as growing media for greenhouse cultures. Acta Hort. 342:127-142.

Jordahl, J.L. and D.L. Karlen. 1993. Comparison of alternative farming systems. III. Soil aggregate stability. Amer. J.Alternative Agr. 8(1):27-33.

Korner, I. and R. Stegmann. 1998. Influence of biowaste composition and composting parameters on the nitrogen dynamics during composting and on nitrogen contents in composts. Acta Hort. 469:97-109.

Larsen, K.L. and D.M. McCartney. 2000. Effect of C:N ratio on microbial activity and $\mathrm{N}$ retention: Bench-scale study using pulp and paper biosolids. Compost Sci. Utilization 8:147-159.
Lee, J.J., R.D. Park, Y.W. Kim, J.H. Shim, D.H. Chae, Y.S. Rim, B.K. Sohn, T.H. Kim, and K.Y. Kim. 2004. Effect of food waste compost on microbial population, soil enzyme activity and lettuce growth. Bioresource Technol. 93:21-8.

Lumsden, R.D., P.D. Millner, and J.A. Lewis, 1986. Suppression of lettuce drop caused by Sclerotinia minor with composted sewage sludge. Plant Dis. 70:197-201.

Mandelbaum, R. and Y. Hadar. 1990. Effects of available carbon source on microbial activity and suppression of $P y$ thium aphanidermatum in compost and peat container media. Phytopathology 80:794-804

Mandelbaum, R., Y. Hadar, and Y. Chen. 1988. Composting of agricultural wastes for their use as container media: Effect of heat treatments on suppression of Pythium aphanidermatum and microbial activities in substrates containing compost. Biolog. Wastes 26:261-274.

Martins, O. and T. Dewes. 1992. Loss of nitrogenous compounds during composting of animal wastes. Bioresource Technol. 42:103-111.

Mathur, S.P., M. Schnitzer, and P. Schuppli., 1990. The distribution of nitrogen in peat-based composts of manure slurries and fisheries wastes. Biol. Agr. Hort. 7:153-163

Michel, Jr., F.C. and C.A. Reddy. 1998. Effect of oxygenation level on yard trimmings composting rate, odor production, and compost quality in bench-scale reactors. Compost Sci. Utilization 6(4):6-14.

Miller, F.C. and F.B. Metting, Jr. 1992. Composting as a process based on the control of ecologically selective factors, $\mathrm{p}$. 515-544. In: Soil microbial ecology: Applications in agricultural and environmental management. Marcel Dekker, New York.

Miller, J.H. and N. Jones. 1995. Organic and compost-based growing media for tree seedling nurseries. World Bank Tech. Paper No. 264, Washington, D.C.

Nappi, P. and R. Barberis. 1993. Compost as growing medium: Chemical, physical and biological aspects. Acta Hort. 342:249-256.

Nelson, E.B. and H.A.J. Hoitink. 1983. The role of microorganisms in the suppression of Rbizoctonia solani in container media amended with composted hardwood bark. Phytopathology 73:274-278.

Pages, M., V. Estaun, and C. Calvet. 1985. Physical and chemical properties of olive marc compost. Acta Hort. 172:271-276.

Pokorny, F.A. 1979. Pine bark container media: An overview. Intl. Plant Prop. Soc. Combined Proc. 29:484-495. 
Pudelski, T. 1985. Woodwaste composts as growing media for vegetables under protection. Acta Hort. 172:67-74.

Punshon, T., D.C. Adriano and J.T. Weber. 2002. Restoration of drastically eroded land using coal fly ash and poultry biosolid. Sci. Total Environ. 16: 209-225.

Raviv, M. 1998a. Horticultural use of composted materials. Acta Hort. 469:225-234.

Raviv, M., Y. Chen, and Y. Inbar. 1986. Peat and peat substitutes as growth media for container-grown plants, p. 257-287. In: Y. Chen and Y. Avnimelech (eds.). Organic matter in modern agriculture. Martinus Nijhof/Dr. W. Junk Publ., Dordrecht, The Netherlands.

Raviv, M. and Sh. Medina. 1997. Physical characteristics of separated cattle manure compost. Compost Sci. Utilization $5: 44-47$.

Raviv, M., Sh. Medina, A. Krasnovsky, and H. Ziadna. 2004. Organic matter and nitrogen conservation in dairy manure composting for organic agriculture. Compost Sci. Utilization 12:6-10.

Raviv, M., Sh. Medina, and Y. Shamir. 1999. Cocomposting - A method to improve results of poultry manure composting. Compost Sci. Utilization 7(2):70-73.

Raviv, M., R. Reuveni, and B. Zaidman. 1998b. Improved medium for organic transplants. Biol. Agr. Hort. 16:53-64.

Raviv, M., R. Reuveni, A. Krasnovsky, Sh. Medina, L. Freiman, and A. Bar. 1998d. Compost as a controlling agent against fusarium wilt of sweet basil. Acta Hort. 469:375-381

Raviv, M., S. Tarre, Z. Geler, and G. Shelef. 1987. Changes in some physical and chemical properties of fibrous solids from cow manure and digested cow manure during composting. Biolog. Wastes 19:309-318.
Raviv, M., R. Wallach, A. Silber, and A. Bar-Tal. 2002. Substrates and their analysis, p. 25-102. In: D. Savva and H. Passam (eds.). Hydroponic production of vegetables and ornamentals. Embryo Publ., Athens, Greece.

Raviv, M., B. Zaidman, and Y. Kapulnik. $1998 \mathrm{c}$. The use of compost as a peat substitute for organic vegetable transplants production. Compost Sci. Utilization $6: 46-52$.

Reuveni, R., M. Raviv, A. Krasnovsky, L. Freiman, Sh. Medina, A. Bar, and D. Orion. 2002. Compost induces protection against Fusarium oxysporum in sweet basil. Crop Protection 21:583-587.

Riviere, L.M. and C. Milhau. 1984. The use of wood waste composts in the making of substrates for container crops. Acta Hort. 150:475-489.

Romkens, P.F.A.M., J.van der Plicht, and J. Hassink. 1999. Soil organic matter dynamics after the conversion of arable land to pasture. Biol. Fertility Soils 28:277-284.

Sanchez-Monedero, M.C., M.P. Bernal,A. Roig, J. Cegarra, and D. Garcia. 1996. The effectiveness of the Rutgers system and the addition of bulking agent in reducing $\mathrm{N}$ losses during composting, p. 133-139. In: Progress in nitrogen cycling studies. Proc. 8th Nitrogen Wrkshp. Kluwer Academic Publ., Dordrecht, The Netherlands,

Sela, R., T. Goldrat, and Y. Avnimelech. 1998. Determining optimal maturity of compost used for land application. Compost Sci. Utilization 6(1):83-88.

Sikora, L.J. and W.J. Rawls. 2000. In situ respiration determination as tool for classifying soils according to soil organic matter content. Commun. Soil Sci. Plant Anal. 31:2793-2801.

Tiquia, S.M. and N.F.Y Tam. 2000. Fate of nitrogen during composting of chicken litter. Environ. Pollution 110:535-541.
Trochoulias, T., A.J. Burton, and E. White. 1990. The use of bagasse as a potting medium for ornamentals. Sci. Hort. 42:161-167.

Vallini, G., A. Pera, E. Nizzi, L. Tortorella, and A. Ciurli. 1992. Vegetable residues from garden/produce markets as recyclable biomass for high-quality compost production. Acta Hort. 302:363-368.

van de Kamp, M. 1986. Apple pomace can be productive. Biocycle 27(3):39.

Vuorinen, A.H. and M.H. Saharinen. 1998. Effects of process conditions on composting efficiency and nitrogen immobilization during composting of manure in a drum composting system. Acta Hort. 469:89-95.

Wang, Y.-T. 1991. Evaluation of media consisting of a cotton waste for the production of tropical foliage species. J. Environ. Hort. 9:112-115.

Williams, K.A. and P.V. Nelson. 1992. Low, controlled nutrient availability provided by organic waste materials for chrysanthemum. J. Amer. Soc. Hort. Sci. 117:422-429.

Witter, E. and H. Kirchmann. 1989. Peat, zeolite and basalt as adsorbents of ammoniacal nitrogen during manure decomposition. Plant Soil 115:43-52.

Wolf, B. and G.H. Snyder. 2003. Sustainable soils. Haworth Press, New York.

Worrall, R. 1978. The use of composted wood waste as a peat substitute. Acta Hort. 82:79-86.

Wu, L., L.Q. Ma, and G.A. Martinez. 2000. Comparison of methods for evaluating stability and maturity of biosolids compost. J. Environ. Quality 29:424-429.

Zeytin, A. and S. Baran. 2003. Influences of composted hazelnut husk on some physical properties of soils. Bioresource Technol. 88:241-244. 